\title{
Study Site Personnel
}

National Cancer Institute

\section{Source}

National Cancer Institute. Study Site Personnel. NCI Thesaurus. Code C93442.

A person who performs a particular role within the context of a specific study site. 